\title{
Lignans from the Roots of Wikstroemia indica and Their DPPH Radical Scavenging and Nitric Oxide Inhibitory Activities ${ }^{1)}$
}

\author{
Li-Yan Wang, Noriko Unehara, and Susumu KitanaKA* \\ Department of Pharmacognosy, College of Pharmacy, Nihon University; 7-7-1 Narasinodai, Funabashi, Chiba 274-8555, \\ Japan. Received May 23, 2005; accepted July 19, 2005; published online July 27, 2005
}

\begin{abstract}
In our investigation of in vitro anti-allergic screening of medicinal herbal extracts, the ethyl acetate extract of the root of Wikstroemia indica was observed to inhibit nitric oxide (NO) production in a lipopolysaccharide (LPS) and recombinant mouse interferon- $\gamma$ (IFN- $\gamma$ ) activated murine macrophage-like cell line, RAW 264.7. Fractionation of the active extract led to the isolation of two new lignan dimer bis-5,5-nortrachelogenin (1) and bis-5,5'-nortrachelogenin (2), and three known lignans. Compound 1 and lirioresinol B (5) inhibited NO production with $\mathrm{IC}_{50}$ values at 48.6 and $53.5 \mu \mathrm{M}$, respectively. Compound 5 also showed free radical scavenging effect on 1,1-diphenyl-2-picrylhydrazil (DPPH) at $\mathrm{IC}_{50}$ values at $19.5 \mu \mathrm{M}$.
\end{abstract}

Key words Wikstroemia indica; Thymelaeaceae; bis-5,5-nortrachelogenin; bis-5,5'-nortrachelogenin; dilignan; nitric oxide

Wikstroemia indica (Thymelaeaceae) is distributed in the southeast of China. It has long been used as a traditional crude drugs for the treatment of pneumonia, rheumatism, and bronchitis ${ }^{2}$ in China. In the previous paper, we reported the isolation of one new guaiane type sesquiterpene, indicanone, and two known biflavonoids, sikokianin B and sikokianin C from $80 \%$ methanol extract of the roots of Wikstroemia indica. ${ }^{3)}$ Indicanone inhibited nitric oxide (NO) production with $\mathrm{IC}_{50}$ values at $9.3 \mu \mathrm{M}$ and also inhibit the iNOS gene expression. Further fractination of the $80 \%$ methanol extract has lead to the isolation of two new dilignans, and three known lignans. In this paper, we report the structure characterization and the NO and 1,1-diphenyl-2-picrylhydrazil (DPPH) evaluation of these compounds.

The IR spectrum of 1 showed absorptions at $3440(\mathrm{OH})$ and 1770 ( $\gamma$-lactone). The ${ }^{1} \mathrm{H}$ spectrum of 1 exhibited the presence of two methoxyls $\left(\delta_{\mathrm{H}} 3.86 \mathrm{~s} 3 \mathrm{H}, \delta_{\mathrm{H}} 3.69 \mathrm{~s} 3 \mathrm{H}\right)$, a set of $\mathrm{AB}$ system signals of a methylene $\left[\delta_{\mathrm{H}} 2.87 \mathrm{~d}(13.0)\right.$, $3.10 \mathrm{~d}(13.0)]$, a 1,2,4-trisubstituted benzene ring $\left[\delta_{\mathrm{H}} 6.70 \mathrm{~d}\right.$ $\left.(1.8), \delta_{\mathrm{H}} 6.55 \mathrm{dd}(8.0,1.8), \delta_{\mathrm{H}} 6.66 \mathrm{~d}(8.0)\right]$, and a $1,2,3,5-$ tetrasubstituted benzene ring $\left[\delta_{\mathrm{H}} 6.67 \mathrm{~d}(3.1), \delta_{\mathrm{H}} 6.69 \mathrm{~d}\right.$ (3.1)]. The ${ }^{1} \mathrm{H}$ spectrum of $\mathbf{1}$ showed a very similar pattern to that of 3 (Table 1), ${ }^{4}$ a known compound named $(+)$-nortrachelogenin which was isolated from this plant formerly, except for the difference in the aromatic region. That is, the signals of 1,2,4-trisubstituted benzene ring due to the aromatic ring B of $\mathbf{3}\left[\delta_{\mathrm{H}} 6.66 \mathrm{~d}(2.1), \delta_{\mathrm{H}} 6.69 \mathrm{~d}(8.0), \delta_{\mathrm{H}} 6.58 \mathrm{dd}(8.0\right.$, $2.1)]$ was changed to be two meta-coupling signals. The distortionless enhancement by polarization transfer (DEPT) spectrum of $\mathbf{1}$ were compared to those of $\mathbf{3}$ and found they showed a completely identical pattern except that C-5 in the aromatic ring of 1 changed to be a quaternary carbon, whereas $\mathrm{C}-5$ in the same aromatic ring of $\mathbf{3}$ appeared as a tertiary carbon bearing one aromatic proton. Electron impact ionization (EI)-MS showed $[\mathrm{M}]^{+}$at $\mathrm{m} / \mathrm{z} 746$, which corresponding to MW of a dimer of 3 [ $2 \times 374$ (MW of $\mathbf{3}$ ) $-2 \mathrm{H}]$. The high resolution (HR)-EI-MS of $\mathbf{1}$ indicated a molecular ion at $\mathrm{m} / z$ 746.2551, which corresponded to the molecular formula $\mathrm{C}_{40} \mathrm{H}_{46} \mathrm{O}_{12}$. From all these results, $\mathbf{1}$ was suggested to be a dimer of 3 and the two nortrachelogenin (3) units were linked in a magnetically symmetric mode at $\mathrm{C}-5$. The $\mathrm{C}-5$ symmetric dilignan of $\mathbf{1}$ was also supported by the down field shifts of C-5 and C-6 $\left[\Delta \delta_{\mathrm{C}}=+11.0,+2.4,\left(\Delta \delta_{\mathrm{C}}=\delta \mathbf{1}-\delta \mathbf{3}\right)\right]$, and up field shifts of C-4 $\left[\Delta \delta_{\mathrm{C}}=-2.5\right]$. The relative stereochemistry of butyrolactone ring was assigned on the basis of nuclear magnetic resonance (NOESY) experiment. $\delta_{\mathrm{H}} 3.10$ $\left(\mathrm{H}^{-} 7^{\prime}\right)$ showed a NOE correlation with $\delta_{\mathrm{H}} 2.46(\mathrm{H}-8)$ indicated a $8 \alpha-\mathrm{H}, 8^{\prime} \beta-\mathrm{OH}$. Based on the above evidence, 1 was identified as a new dilignan, bis-5,5-nortrachelogenin.

The molecular composition of $\mathbf{2}$ was found to be $\mathrm{C}_{40} \mathrm{H}_{42} \mathrm{O}_{14}$, the same as $\mathbf{1}$, by the negative high resolution FAB-MS (HR-FAB-MS) $(m / z$ 745.2489). 2 displayed IR absorptions at $3360(\mathrm{OH})$ and $1750\left(\gamma\right.$-lactone). ${ }^{1} \mathrm{H}-$ and ${ }^{13} \mathrm{C}$ NMR spectra of $\mathbf{2}$ showed two pairs signal of $\mathbf{3}$ (Table 1). This suggested that $\mathbf{2}$ was a dimeric lignan of $\mathbf{3}$ and the two units linked in an asymmetric mode. The ${ }^{1} \mathrm{H}-\mathrm{NMR}$ spectrum of 2 exhibited the presence of four methoxyls $\left(\delta_{\mathrm{H}} 3.62 \mathrm{~s} 3 \mathrm{H}\right.$, $\left.\delta_{\mathrm{H}} 3.68 \mathrm{~s} 3 \mathrm{H}, \delta_{\mathrm{H}} 3.83 \mathrm{~s} 3 \mathrm{H}, \delta_{\mathrm{H}} 3.86 \mathrm{~s} 3 \mathrm{H}\right)$, two sets of AB system signals of two methylenes $\left[\delta_{\mathrm{H}} 2.86 \mathrm{~d}(13.7), 3.10 \mathrm{~d}\right.$ (13.7); $\left.\delta_{\mathrm{H}} 2.90 \mathrm{~d}(13.4), 3.17 \mathrm{~d}(13.4)\right]$, two 1,2,4-trisubstituted benzene rings $\left[\delta_{\mathrm{H}} 6.68 \mathrm{~d}(1.8), \delta_{\mathrm{H}} 6.55 \mathrm{dd}(7.9,1.8)\right.$, $\delta_{\mathrm{H}} 6.65 \mathrm{~d}(7.9), \delta_{\mathrm{H}} 6.62 \mathrm{~d}(1.8), \delta_{\mathrm{H}} 6.64 \mathrm{~d}(7.9), \delta_{\mathrm{H}} 6.56 \mathrm{dd}$ $(7.9,1.8)]$, and two $1,2,3,5$-tetrasubstituted benzene rings [ $\delta_{\mathrm{H}}$ $6.66 \mathrm{~d}(1.8), \delta_{\mathrm{H}} 6.69 \mathrm{~d}(1.8), \delta_{\mathrm{H}} 6.70 \mathrm{~d}(1.8), \delta_{\mathrm{H}} 6.72 \mathrm{~d}$ (1.8)]. The ${ }^{13} \mathrm{C}$-NMR and DEPT spectra of 2 also showed the presence of four aromatic rings (A, B, C, D), two carbonyls, four methoxyls, two oxygen-bearing methylenes, two oxygen-bearing quaternary carbons, four methylenes, and two methines. By the analysis of the ${ }^{1} \mathrm{H}-{ }^{1} \mathrm{H}$ correlation spectroscopy $\left({ }^{1} \mathrm{H}-{ }^{1} \mathrm{H}\right.$ COSY $)$ and heteronuclear multiplequatum coherence (HMQC) spectrum, the correlation of H-8 $\left(\delta_{\mathrm{H}}\right.$ $2.58 \mathrm{~m})$ with H-9 $\left(\delta_{\mathrm{H}} 4.05 \mathrm{~m}\right)$ and H-7 $\left(\delta_{\mathrm{H}} 2.55 \mathrm{~m}, 2.82 \mathrm{~m}\right)$, and $\mathrm{H}-8^{\prime \prime}$ with $\mathrm{H}-9^{\prime \prime}$ and $\mathrm{H}-\mathrm{7}^{\prime \prime}$ gave the partial structure $\mathrm{C}$ 7-C-9 and C-7"-C-9". In the analysis of heteronuclear multiplebond connectivity (HMBC) spectrum, the long-range correlations of the carbons $\left(\mathrm{C}-7-\mathrm{C}-9\right.$ and $\left.\mathrm{C}-7^{\prime}-\mathrm{C}-9^{\prime}\right)$ with proton signals $\left(\mathrm{H}-7-\mathrm{H}-9\right.$ and $\left.\mathrm{H}-7^{\prime}\right)$ connected the partial structure C-7-C-9 with C-7'-C-9' and established the partial structure I. The chemical shift of C-9 $\left(\delta_{\mathrm{C}} 72.0\right)$ and C-9' $\left(\delta_{\mathrm{C}}\right.$ 180.8), and the HMBC correlation between H-9 and C- $9^{\prime}$ confirmed the lactone unit at C-9 and C-9'. The same partial structure II (C-7"-C-9" and C-7"'-C-9"') was ascertained in the same manner (Fig. 2). Furthermore, the HMBC spectrum showed correlations between $\mathrm{H}-8$ and $\mathrm{C}-1, \mathrm{H}-7$ and $\mathrm{C}-1, \mathrm{C}-2$, 
Table 1. ${ }^{1} \mathrm{H}$ - and ${ }^{13} \mathrm{C}-\mathrm{NMR}$ Data for Compounds $\mathbf{1}, \mathbf{2}$, and $\mathbf{3}\left[\mathrm{CD}_{3} \mathrm{OD} \text {, TMS, } \delta(\mathrm{ppm})(J=\mathrm{Hz})\right]^{a}$

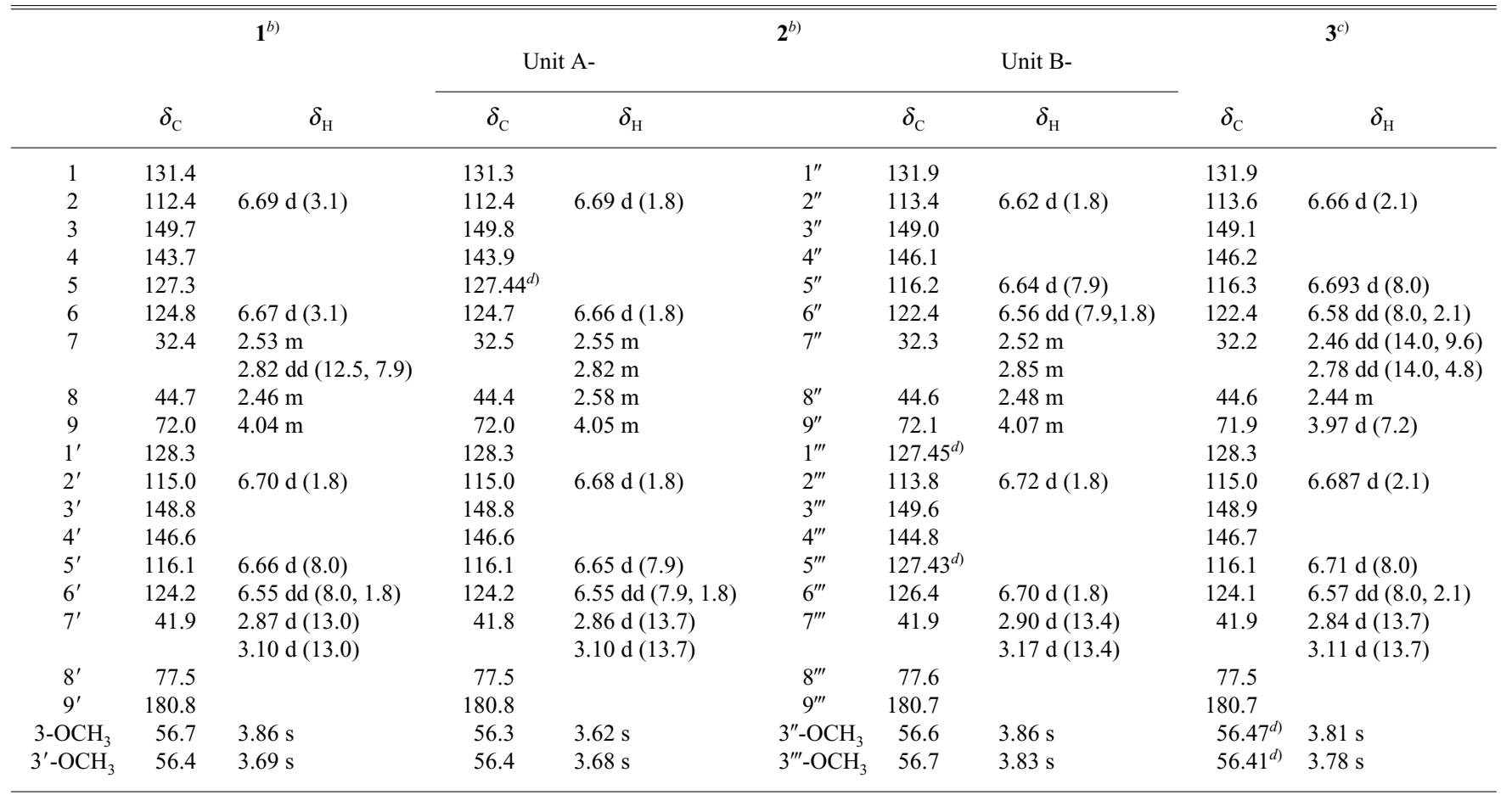

a) Assignments confirmed by decoupling, ${ }^{1} \mathrm{H}-{ }^{1} \mathrm{H}$ COSY, HMQC, HMBC, and NOESY spectra. b) Spectra obtained at $500 \mathrm{MHz}$ and $125 \mathrm{MHz}$. c) Spectra obtained at $600 \mathrm{MHz}$ and $150 \mathrm{MHz}$. d) Interchangeable signal.

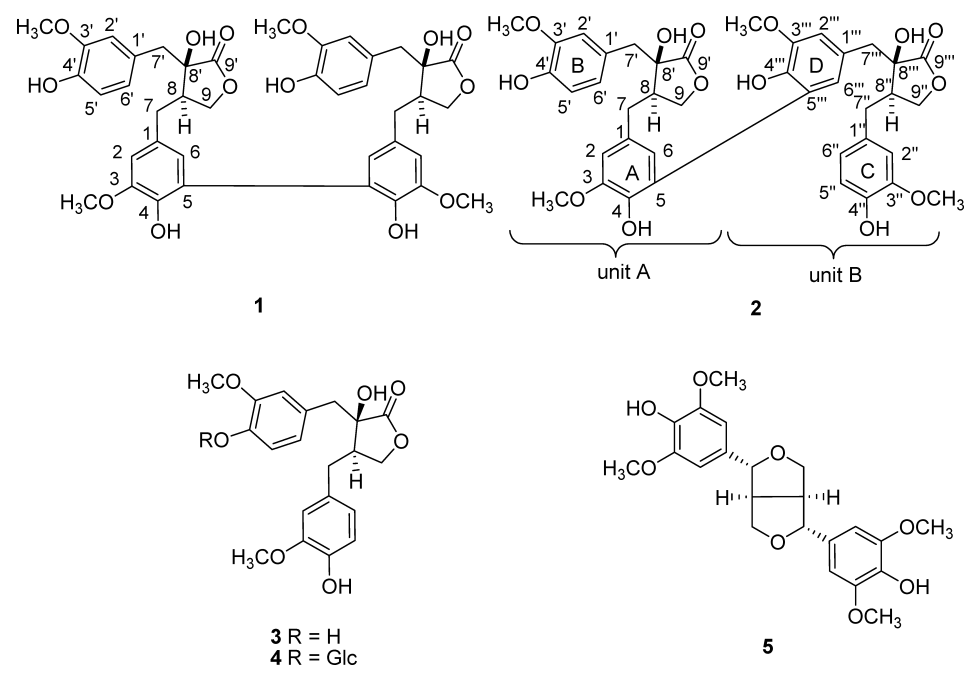

Fig. 1. Structures of Compounds $\mathbf{1}-\mathbf{5}$ from the Roots of Wikstroemia indica

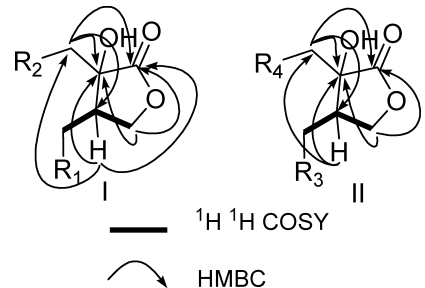

Fig. 2. ${ }^{1} \mathrm{H}-{ }^{1} \mathrm{H}$ COSY and Key HMBC Correlations of Partial Structure I and II

and C-6, H-2 and C-1, C-3, C-4, and C-7, H-6 and C-1, C-4, $\mathrm{C}-5$, and $\mathrm{C}-7$. From these results, the assignments at benzene ring $\mathrm{A}$ were confirmed and the benzene ring $\mathrm{A}$ was con- nected with $\mathrm{C}-7$ at $\mathrm{C}-1$. The $\mathrm{HMBC}$ correlations of $\mathrm{H}-7^{\prime}$ to $\mathrm{C}-1^{\prime}, \mathrm{C}-2^{\prime}$, and $\mathrm{C}-6^{\prime}, \mathrm{H}-2^{\prime}$ to $\mathrm{C}-1^{\prime}, \mathrm{C}-3^{\prime}$, and $\mathrm{C}-7^{\prime}$, and $\mathrm{H}-6^{\prime}$ to $\mathrm{C}-1^{\prime}, \mathrm{C}-4^{\prime}$, and $\mathrm{C}-5^{\prime}$ confirmed the assignments at benzene ring $\mathrm{B}$ and the benzene ring $\mathrm{B}$ was connected with $\mathrm{C}-\mathrm{7}^{\prime}$ at $\mathrm{C}-1^{\prime}$. From these results, the half-structure (Unit A) of 2 was confirmed. The other half-structure of 2 (Unit B) was also confirmed by the same carefully analysis of HMBC correlations (Fig. 3). Since C-5 of unit A and C-5"' of unit B are quaternary carbon, 2 was suggested to be a dilignan linked at C-5 and C-5"'. The C-5,5"' dimmer of 2 was also supported by the down field shifts of C-5 and C- $6\left[\Delta \delta_{\mathrm{C}}=+11.1,+2.3\right.$, $\left.\left(\Delta \delta_{\mathrm{C}}=\delta \mathbf{2}-\delta \mathbf{3}\right)\right]$, and up field shifts of $\mathrm{C}-4\left[\Delta \delta_{\mathrm{C}}=-2.3\right]$ in the unit A, and the down field shifts of C-5"' and C-6"' $\left[\Delta \delta_{\mathrm{C}}=+11.3,+2.3,\left(\Delta \boldsymbol{\delta}_{\mathrm{C}}=\boldsymbol{\delta} \mathbf{2}-\boldsymbol{\delta} \mathbf{3}\right)\right]$, and up field shifts of 


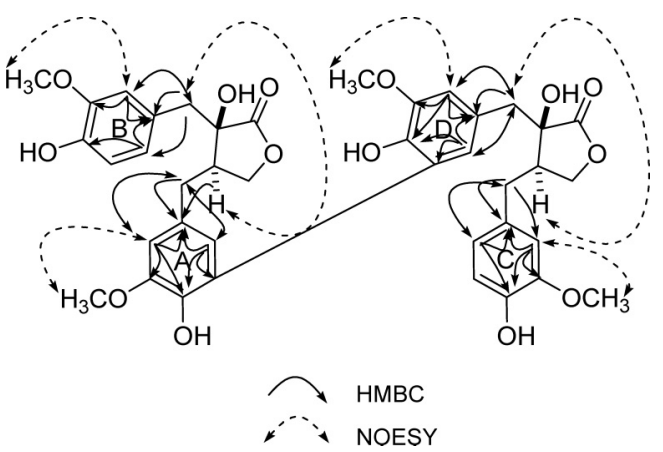

Fig. 3. Key HMBC and NOE Correlations of 2

Table 2. Inhibitory Effects on NO Production and Free Radical Scavenging Effects on DPPH of Compounds $\mathbf{1}-\mathbf{5}$

\begin{tabular}{ccc}
\hline \hline \multirow{2}{*}{ Compounds } & NO & $\mathrm{DPPH}$ \\
\cline { 2 - 3 } & \multicolumn{2}{c}{$\mathrm{IC}_{50}(\mu \mathrm{M})$} \\
\hline $\mathbf{1}$ & 48.6 & 133.2 \\
$\mathbf{2}$ & $>200$ & $>200$ \\
$\mathbf{3}$ & $>200$ & 90.1 \\
$\mathbf{4}$ & $>200$ & 84.2 \\
$\mathbf{5}$ & 53.5 & 19.5 \\
\hline
\end{tabular}

C-4"' $\left[\Delta \delta_{\mathrm{C}}=-1.9\right]$ in the unit B comparing to 3.2 showed the significant NOE correlation between methoxyl $\delta_{\mathrm{H}} 3.62 \mathrm{~s}$ $\left(3-\mathrm{OCH}_{3}\right)$ and $\mathrm{H}-2, \delta_{\mathrm{H}} 3.68 \mathrm{~s}\left(3^{\prime}-\mathrm{OCH}_{3}\right)$ and $\mathrm{H}-2^{\prime}, \delta_{\mathrm{H}} 3.86 \mathrm{~s}$ $\left(3^{\prime \prime}-\mathrm{OCH}_{3}\right)$ and $\mathrm{H}-2^{\prime \prime}, \delta_{\mathrm{H}} 3.83 \mathrm{~s}\left(3^{\prime \prime \prime}-\mathrm{OCH}_{3}\right)$ and $\mathrm{H}-2^{\prime \prime \prime}$. These facts indicated the positions of the methoxyls. $\delta_{\mathrm{H}} 3.10\left(\mathrm{H}-7^{\prime}\right)$ showed a NOE correlation with $\delta_{\mathrm{H}} 2.58(\mathrm{H}-8)$ and $\delta_{\mathrm{H}} 3.17$ $\left(\mathrm{H}-7^{\prime \prime \prime}\right)$ showed a NOE correlation with $\delta_{\mathrm{H}} 2.48\left(\mathrm{H}-8^{\prime \prime}\right)$ indicated a $8 \alpha-\mathrm{H}, 8^{\prime} \beta-\mathrm{OH}$ and $8^{\prime \prime} \alpha-\mathrm{H}, 8^{\prime \prime \prime} \beta-\mathrm{OH}$.

$(+)$-Nortrachelogenin $(3),{ }^{4)}$ nortracheloside $(4),{ }^{5)}$ and lirioresinol B $(\mathbf{5})^{6}$ were known compounds, whose structures were elucidated by comparisons with the literature.

Compounds 1 and $\mathbf{5}$ showed most potent NO production inhibitory activity with $\mathrm{IC}_{50}$ value of 48.6 and $53.5 \mu \mathrm{M}$, which is not stronger than that of $N^{\mathrm{G}}$-monomethyl-L-arginine (L-NMMA) used as a positive control having an $\mathrm{IC}_{50}$ value of $25.5 \mu \mathrm{M}$.

Compounds $\mathbf{1}-\mathbf{5}$ were also tested for their DPPH radical scavenging activity, and all compounds, except $\mathbf{2}$ showed significant scavenging activity. Lirioresinol B (5) possessed the strongest DPPH radical scavenging activity with $\mathrm{IC}_{50}$ value of $19.5 \mu \mathrm{M}$. L-Ascorbic acid, a well known antioxidant used as a positive control, had an $\mathrm{IC}_{50}$ value of $20.3 \mu \mathrm{M}$.

\section{Experimental}

General Procedures The UV spectrum was obtained in $\mathrm{MeOH}$ on a Shimadzu UV-160 spectrophotometer, and the IR spectrum was recorded on a JUSCO FT/300E spectrophotometer. Optical rotations were measured in $\mathrm{MeOH}$ on a JASCO DIP-360 polarimeter. The NMR spectra were recorded on a JNM-ECX-500 and JNM-ECA 600 spectrometer, with TMS as an internal standard. MS was obtained on a JMS GC mate spectrometer. Column chromatography was carried out with silica gel (Wako gel C-300, Wako Pure Chemical Industry Ltd.). Thin-layer chromatography (TLC) was performed on Merck TLC plates $(0.25 \mathrm{~mm}$ thickness), with compounds visualized by spraying with $5 \%(\mathrm{v} / \mathrm{v}) \mathrm{H}_{2} \mathrm{SO}_{4}$ in ethanol solution and then heating on a hot plate. HPLC was performed on a JASCO PU-2089 apparatus equipped with a JASCO UV-2075. YMC pack pro C-18 $(10 \times 250 \mathrm{~mm})$ and Fluofix $(10 \times 250 \mathrm{~mm})$ were used for preparative purposes.
Plant Materials The dried root of $W$. indica was collected in Guangdong Province, People's Republic of China, in October 1998 and was identified by Professor Weichun Wu (Department of Medical Plants, Shenyang Pharmaceutical University, People's Republic of China). Voucher specimens (NK-01017) have been deposited at the Department of Pharmacognosy, College of Pharmacy, Nihon University.

Extraction and Isolation The dried roots of $W$. indica $(2.3 \mathrm{~kg})$ were extracted twice with $80 \%$ methanol. Evaporation of the solvent under reduced pressure from the combined extract gave the $80 \% \mathrm{MtOH}$ extract $286 \mathrm{~g}$ (NO inhibitory effect $100 \mu \mathrm{g} / \mathrm{ml}, 38.2 \%$ ). The extract was dissolved and suspended in water $(21)$ and partitioned with hexane $(3 \times 21)$, ethyl acetate $(3 \times 21)$, and $n$-butanol $(3 \times 21)$. The amounts extracted were $6.5 \mathrm{~g}(76.1 \%)$, $62.0 \mathrm{~g}(86.9 \%)$, and $25.0 \mathrm{~g}(-6.4 \%)$, respectively, and the residual aqueous extract yielded $88.3 \mathrm{~g}(3.8 \%)$.

The ethyl acetate fraction was subjected to sephadex LH-20 column chromatography $\left(13 \times 20 \mathrm{~cm}\right.$, eluted with $\left.\mathrm{MeOH}: \mathrm{H}_{2} \mathrm{O} 30: 70-90: 10\right)$. The column chromatographic fractions $(200 \mathrm{ml}$ each) were combined according to TLC monitoring into four portions. Fraction 2, was subjected to silica gel column chromatography $(3 \times 21 \mathrm{~cm}$, eluted with chloroform and methanol in increasing polarity). The column chromatographic fractions $(100 \mathrm{ml}$ each) were combined according to TLC monitoring into eleven portions. Portion three was isolated and further purified by HPLC (YMC pack pro C-18, $\left.10 \times 250 \mathrm{~mm}, \mathrm{MeOH}: \mathrm{H}_{2} \mathrm{O}, 45: 55\right)$ to give $\mathbf{3}$ and $\mathbf{5}(55.5,10.1 \mathrm{mg})$. Portion five was isolated and further purified by HPLC (Fluofix, $10 \times 250 \mathrm{~mm}$, $\left.\mathrm{MeOH}: \mathrm{H}_{2} \mathrm{O}, 35: 65\right)$ to give 1 and $2(5.7,4.5 \mathrm{mg})$. Portion 7, was further purified by HPLC (YMC pack pro C-18, $10 \times 250 \mathrm{~mm}, \mathrm{MeOH}: \mathrm{H}_{2} \mathrm{O}, 35: 65$ ) to give $4(4.9 \mathrm{mg})$.

Bis-5,5-nortrachelogenin (1): Light yellow oil; $[\alpha]_{\mathrm{D}}^{23}+55.0^{\circ}(c=0.10$, $\mathrm{MeOH}$ ); UV (MeOH) $\lambda_{\max }(\log \varepsilon) \mathrm{nm}: 284$ (4.07), 205 (4.98); IR (KBr) $v_{\max }$ $3440,1770,1600,1520,1460,1430 \mathrm{~cm}^{-1} ; \mathrm{CD}(\mathrm{MeOH}) \lambda_{\text {ext }} 232 \mathrm{~nm}(\Delta \varepsilon$ $+2.48), 205 \mathrm{~nm}(\Delta \varepsilon+3.28) ;{ }^{1} \mathrm{H}-$ and ${ }^{13} \mathrm{C}$-NMR data, see Table 1; HR-EIMS $m / z: 746.2551$ (Calcd for $\mathrm{C}_{40} \mathrm{H}_{42} \mathrm{O}_{14}, 746.2574$ ).

Bis-5,5'-nortrachelogenin (2): Light yellow oil; $[\alpha]_{\mathrm{D}}^{23}+68.1^{\circ}(c=0.42$, $\mathrm{MeOH}$ ); UV (MeOH) $\lambda_{\max }(\log \varepsilon) \mathrm{nm}: 280$ (4.22); IR (liquid film) $v_{\max }$ $3360,1750,1600,1520,1470 \mathrm{~cm}^{-1} ; \mathrm{CD}(\mathrm{MeOH}) \lambda_{\text {ext }} 232 \mathrm{~nm}(\Delta \varepsilon+2.41)$, $205 \mathrm{~nm}(\Delta \varepsilon+2.31) ;{ }^{1} \mathrm{H}$ - and ${ }^{13} \mathrm{C}-\mathrm{NMR}$ data, see Table 1 ; negative HR-FABMS $m / z: 745.2489$ (Calcd for $\mathrm{C}_{40} \mathrm{H}_{41} \mathrm{O}_{14}, 745.2495$ ).

$(+)$-Nortrachelogenin (3): See ref. 4; CD (MeOH) $\lambda_{\text {ext }} 234 \mathrm{~nm}(\Delta \varepsilon$ $+2.62), 206 \mathrm{~nm}(\Delta \varepsilon+3.28)$.

Inhibitory Activity on NO Production from Activated MacrophagesLike Cell Line, RAW 264.7 The cells were seeded at $1.2 \times 10^{6}$ cells $/ \mathrm{ml}$ onto 96 -well flat bottom plate and then incubated at $37^{\circ} \mathrm{C}$ for $2 \mathrm{~h}$. Next, the test sample was added to the culture simultaneously with both Escherichia coli LPS $(100 \mathrm{ng} / \mathrm{ml})$ and recombinant mouse IFN- $\gamma(0.33 \mathrm{ng} / \mathrm{ml})$. Then cells were incubated at $37^{\circ} \mathrm{C}$ for approximately $16 \mathrm{~h}$ and subsequently chilled on ice. One hundred microliters of the culture supernatant was placed in duplicate in the wells of 96-well flat-bottomed plates. A standard solution of $\mathrm{NaNO}_{2}$ was placed in alternate wells on the same plate. To quantify nitrite, $50 \mu \mathrm{l}$ of Griess reagent $\left(1 \%\right.$ sulfanilamide in $5 \% \mathrm{H}_{3} \mathrm{PO}_{4}$ and $0.1 \% \mathrm{~N}$-1-naphthylethylenediamide dihydrochloride) was added to each well. After $10 \mathrm{~min}$ the reaction products were colorimetrically quantified at $550 \mathrm{~nm}$ using a Model 3550 Microplate Reader and the background absorbance $(630 \mathrm{~nm})$ was subtracted. Cytotoxicity was measured by the 3-(4,5-dimethylthiazol-2yl)-2,5-diphenyltetrazolium bromide (MTT) assay method.

DPPH Radical Scavenging Activity $0.2 \mathrm{M}$ acetic acid buffer $(40 \mu \mathrm{l})$, $12 \%$ methanol $(40 \mu \mathrm{l})$, and sample $(0.4 \mu \mathrm{l})$ was mixed with $0.5 \mathrm{~mm} \mathrm{DPPH}$ $(40 \mu 1)$. The resulting solution was thoroughly mixed and the absorbance was measures at $520 \mathrm{~nm}$ after $30 \mathrm{~min}$. The scavenging activity was determined by comparing the absorbence with that of the control (100\%) containing only DPPH and solvent.

Acknowledgments This investigation was supported by a Special Research Grant-in-Aid for the Promotion and Mutual Aid Corporation for Private Schools of Japan to Nihon University, and by a grant from the Ministry of Education, Culture, Sports, Science, and Technology to promote Interdisciplinary Studies on Human Health and Diseases based on Molecular Pharmaceutical Sciences and Clinical Applications.

\section{References and Notes}

1) Part 13 in the series of anti-allergic agents from natural sources. Part 12: Ishii R., Horie M., Koyama K., Ishikawa Y., Kitanaka S., Biol. Pharm. Bull., 28, 786-790 (2005).

2) "Zhong Hua Ben Cao," Shanghai Xin Hua Press, Shanghai, 1999, pp. $425-426$. 
3) Wang L. Y., Unehara N., Kitanaka S., Chem. Pharm. Bull., 53, 137139 (2005).

4) Kato A., Hashimoto Y., Kidokoro M., J. Nat. Prod., 42, 159-162 (1979).
5) Li T. Z., Zhang W. D., Gu Z. B., Liu W. Y., Zhou J., Chen W. S., Yao Хие Хие Вао, 38, 520-522 (2003).

6) Tong W. Y., Mi L., Liang H., Zhao Y. Y., Beijing Daxue Xuebao, Yixueban, 35, 180-183 (2003). 